\title{
Isovitexin Increases Stem Cell Properties and Protects Against PM2.5 in Keratinocytes
}

\author{
VERISA CHOWJAREAN ${ }^{1,2}$, TASSANEE PRUEKSASIT ${ }^{3}$, \\ KEERATI JOYJAMRAS ${ }^{4,5,6}$ and PITHI CHANVORACHOTE ${ }^{4,6}$ \\ ${ }^{1}$ Cosmeceutical Research, Development and Testing Center, \\ College of Pharmacy, Rangsit University, Pathumthani, Thailand; \\ ${ }^{2}$ Department of Pharmaceutical Technology, College of Pharmacy, Rangsit University, Pathumthani, Thailand; \\ ${ }^{3}$ Department of Environmental Science, Faculty of Science, Chulalongkorn University, Bangkok, Thailand; \\ ${ }^{4}$ Cell-based Drug and Health Products Development Research Unit, \\ Faculty of Pharmaceutical Sciences, Chulalongkorn University, Bangkok, Thailand; \\ ${ }^{5}$ Doctor of Philosophy Program in Pharmaceutical Sciences and Technology, \\ Faculty of Pharmaceutical Sciences, Chulalongkorn University, Bangkok, Thailand; \\ ${ }^{6}$ Department of Pharmacology and Physiology, Faculty of Pharmaceutical Sciences, \\ Chulalongkorn University, Bangkok, Thailand
}

\begin{abstract}
Background/Aim: Fine airborne particles of Particular Matter of less than 2.5 micrometers $\left(P M_{2.5}\right)$ have been recognized as a dominant air contamination causing critical health concerns. Herein, we determined whether isovitexin, a natural plant-derived compound could protect PM 2.5 -mediated oxidative stress and induce stemness in epidermal cells. Materials and Methods: Cell viability was detected by the 3-(4,5dimethylthiazol-2-yl)-2,5 diphenyltetrazolium bromide (MTT) assay. Reactive oxygen species (ROS) were determined by flow cytometry with 2',7'-dichlorofluorescin diacetate (DCFH-DA). Protein hallmarks of stem cells were examined by western blot analysis. Results: $P M_{2.5}$ treatment for 30 min increased the levels of intracellular ROS. Pre-treatment of cells with 10-50 $\mu \mathrm{M}$ of isovitexin dramatically inhibited the ROS induced by $P M_{2.5}$. Antioxidant efficacy of isovitexin was also determined by the ROS scavenging activity against 2,2-diphenyl-2-picrylhydrazyl $(D P P H), A B T S$ and superoxide anion radicals. In addition, we found that isovitexin enhanced the stem cell properties of keratinocytes, indicated by the significant increase in the levels
\end{abstract}

This article is freely accessible online.

Correspondence to: Pithi Chanvorachote and/or Keerati Joyjamras, Department of Pharmacology and Physiology, Faculty of Pharmaceutical Sciences, Chulalongkorn University, Bangkok, Thailand. Tel: +66 812075039, e-mail: pithi.c@ chula.ac.th; e-mail: j_keerati@hotmail.com

Key Words: Isovitexin, particular matter, PM2.5, reactive oxygen species, oxidative stress. of stem cell proteins. Conclusion: Isovitexin can be potentially used as an effective compound for preventing skin damage.

Environmental pollution is one of the critical factors contributing to health problems (1). Airborne particular matters are air pollutants that have been recognized as a major health concern recently (2). Particular matter (PM) that is less than 2.5 microns in diameter, known as $\mathrm{PM}_{2.5}$, is originated from incomplete combustion in the industry and burning of fuel in urban areas (3). Due to each small size, $\mathrm{PM}_{2.5}$, easily escapes from the respiratory protection of nasal hair and penetrates into the bloodstream. Several epidemiological and toxicological studies have shown that $\mathrm{PM}_{2.5}$ affects various organs in the body such as the lungs (4), nervous system (5), and the inflammatory system (6).

As skin is the outmost body organ exposed to airborne pollution, a previous study showed that $\mathrm{PM}_{2.5}$ may cause allergic skin reaction (7). In addition, exposure to a high concentration of $\mathrm{PM}_{2.5}$ increases dark spots and wrinkles on skin (8). Regarding the mechanisms of action of $\mathrm{PM}_{2.5}$ it has been shown to induce the production of reactive oxygen species (ROS) contributing to cell and tissue damage (9). Oxidative stress plays an important role in the aging process of the skin (10). Although the potential benefits of antioxidants have been well established, the effect of antioxidants on $\mathrm{PM}_{2.5}$-induced ROS in human skin cells still needs further investigation.

Among the various natural antioxidants, isovitexin (apigenin-6-C-glucoside; Figure 1), an isomer of vitexin, is a major bioactive compound from mistletoe fig (11), bamboo (12), mimosa (13). Isovitexin has been reported to possess antioxidant properties (14), $\alpha$-glucosidase-inhibitory activity 
(15), and anti-melanogenesis activity (16). In this study, we investigated whether isovitexin can inhibit ROS generation in human keratinocytes induced by $\mathrm{PM}_{2.5}\left(\mathrm{PM}_{2.5}\right)$, collected from the atmosphere in the roadside of Phayathai road, Pathumwan District, Bangkok, Thailand.

\section{Materials and Methods}

Chemicals and reagents. The isovitexin was purchased form Chengdu Biopurify Phytochemicals (Sichuan, PR China). All the other chemicals and reagents were obtained from Sigma Chemical Inc. (St. Louis, MO, USA). Dulbecco's modified Eagle's medium (DMEM), fetal bovine serum (FBS), L-glutamine, penicillin, streptomycin, phosphate-buffered saline (PBS), trypsin, and EDTA were purchased from Gibco (Waltham, MA, USA).

\section{Determination of antioxidant activity of isovitexin}

DPPH assay. The 2,2-diphenyl-2-picrylhydrazyl (DPPH) radical scavenging activity of isovitexin was investigated using the DPPH assay. The samples were added to $0.15 \mathrm{mM}$ DPPH solution in ethanol in a 96-well plate, and then incubated for $30 \mathrm{~min}$ in the dark at room temperature. The absorbance was determined using the UVspectrophotometer at $517 \mathrm{~nm}$. The results were presented as $\%$ inhibition of DPPH. DPPH solution with the vehicle was used as a negative control and the vehicle without DPPH solution was used as a blank for background subtraction.

ABTS radical scavenging activity. The samples $(20 \mu \mathrm{l})$ were added into a 96-well plate before adding $180 \mu \mathrm{l}$ of $\mathrm{ABTS}^{\bullet+}$ solution, then mixed on a shaker and incubated in the dark at room temperature for 5 min. The absorbance of the $\mathrm{ABTS}^{\bullet+}$ was determined using the $\mathrm{UV}$-spectrophotometer at $750 \mathrm{~nm}$. The results were expressed as $\%$ inhibition of $\mathrm{ABTS}^{\bullet+}$ by isovitexin compared to the $\mathrm{ABTS}^{\bullet+}$ solution with the vehicle, used as the negative control. A $50 \%$ reduction of $\mathrm{ABTS}^{\bullet+}$ was calculated and is shown as an $\mathrm{IC}_{50}$ value.

Superoxide anion radical scavenging activity (SOSA) determination. Each well of a 96-well plate included: $20 \mu \mathrm{l}$ of each sample, $20 \mu \mathrm{l}$ phosphate buffer, $80 \mu \mathrm{l} \mathrm{NADH,} 80 \mu \mathrm{l} \mathrm{NBT}$, and $20 \mu \mathrm{l} \mathrm{PMS}$. The solutions were incubated for $15 \mathrm{~min}$ in the dark at room temperature. The absorbance of the solution at $560 \mathrm{~nm}$ was measured using the UV-spectrophotometer. The results are shown as $\%$ inhibition of SOSA by isovitexin compared to vehicle. $\mathrm{IC}_{50}$ values represent concentration that caused $50 \%$ reduction in the superoxide anion radical levels.

$P M_{2.5}$ sampling and preparation. $\mathrm{PM}_{2.5}$ samples were collected continuously for 24-h from roadside areas located on Phayathai Road, Pathumwan District, Bangkok, Thailand. A personal modular impactor (PMI) containing polytetrafluoroethylene (PTFE) filter ( $37 \mathrm{~mm}$ in diameter and $2 \mu \mathrm{m}$ pore size) connected to a personal air pump (SKC Airchek sampler) was used for collecting $\mathrm{PM}_{2.5}$. It was placed above ground level 5-10 m away from the main road. The instrument was operated at the air flow rate of $31 / \mathrm{min}$.

After sampling, the PTFE filters were extracted according to the method of Rong Hu et al. (17). The PTFE filters were cut into $1 \times 1 \mathrm{~cm}^{2}$ pieces, immersed in deionized water, and sonicated three times for 20 min at $30 \mathrm{kHz}$. The resulting suspensions were filtered, freeze-dried in a vacuum overnight, and then stored at $-80^{\circ} \mathrm{C}$ in the dark. The samples were made at $3 \mathrm{mg} / \mathrm{ml}$ concentration in sterile phosphate-buffered saline (PBS) and then sonicated for $15 \mathrm{~min}$ before use.

Cell culture. The human keratinocyte (HaCaT) cells were obtained from Cell Lines Service (CLS, Heidelberg, Germany) and cultured in Dulbecco's modified Eagle's medium (DMEM) supplemented with fetal bovine serum (FBS) and L-glutamine. Cell cultures were maintained in a $37^{\circ} \mathrm{C}$ with $5 \% \mathrm{CO}_{2}$. Cells were passaged at a preconfluent density using a $0.25 \%$ trypsin solution with $4 \mathrm{mM}$ EDTA.

Cell viability assay. The 3-(4,5-dimethylthiazol-2-yl)-2,5diphenyltetrazolium bromide (MTT) assay was used to determine cell viability. Cells were seeded at a density of $1 \times 10^{4}$ cells/well in 96-well plates and incubated at $37^{\circ} \mathrm{C}$ overnight. The cells were then incubated with different concentrations of isovitexin $(0-250 \mu \mathrm{M})$ and $\mathrm{PM}_{2.5}(0-400 \mu \mathrm{g} / \mathrm{ml})$ in DMEM for $24 \mathrm{~h}$. After the indicated treatments, the cells were incubated with $400 \mu \mathrm{g} / \mathrm{ml}$ MTT (Invitrogen, Carlsbad, CA, USA) for $3 \mathrm{~h}$ at $37^{\circ} \mathrm{C}$. The intensity of the absorbance of the MTT product was measured at $570 \mathrm{~nm}$ using a microplate reader (Anthos, Durham, NC). Cell viability was calculated by the following equation:

\section{Cell viability $(\%)=($ A570 of treatment $) /($ A570 of control $) \times 100$}

The treated cells were also stained with $10 \mu \mathrm{M}$ Hoechst 33342 and examined under fluorescent microscope in order to confirm cell death.

Intracellular ROS detection. Cells were seeded at a density of $1 \times 10^{5}$ cells/well onto 24-well plates for $12 \mathrm{~h}$ and incubated with $10 \mu \mathrm{M}$ 2',7'-dichlorofluorescin diacetate (DCFH-DA) in the presence of various concentrations of isovitexin in serum free DMEM for 30 min at $4^{\circ} \mathrm{C}$. Afterwards, DCFH-DA incubated cells were treated with 100 and $200 \mu \mathrm{g} / \mathrm{ml} \mathrm{PM}_{2.5}$ for $30 \mathrm{~min}$ at $37^{\circ} \mathrm{C}$. The intracellular levels of ROS were measured by Guava ${ }^{\circledR}$ easyCyte flow cytometer (Merck, Darmstadt, Germany) and captured by using a fluorescence microscope (Olympus IX5, DP70, Olympus, Tokyo, Japan).

Western blot analysis. HaCaT cells were seeded at a density of $5 \times 10^{5}$ cells/well onto 6-well plates and incubated at $37^{\circ} \mathrm{C}$ overnight. Afterwards, the cells were incubated with different concentrations of isovitexin in DMEM for $48 \mathrm{~h}$. After treatment, cells were incubated with ice-cold lysis buffer containing $20 \mathrm{mM}$ Tris- $\mathrm{HCl}(\mathrm{pH} 7.5), 0.5 \%$ Triton X-100, $150 \mathrm{mM}$ sodium chloride, $10 \%$ glycerol, $1 \mathrm{mM}$ sodium orthovanadate, $50 \mathrm{mM}$ sodium fluoride, $100 \mathrm{mM}$ phenylmethylsulfonylfluoride, and commercial protease inhibitor cocktail (Roche Molecular Biochemicals, Indianapolis, IN, USA) for $30 \mathrm{~min}$. Protein content was then analyzed using BCA protein assay kit (Pierce Biotechnology, Rockford, IL, USA). Equal amounts of proteins (40 $\mu \mathrm{g}$ ) were boiled in Laemmli loading buffer at $95^{\circ} \mathrm{C}$ for $5 \mathrm{~min}$. The proteins were subsequently loaded on $10 \%$ SDS-polyacrylamide electrophoresis gel and transferred onto $0.45 \mu \mathrm{m}$ nitrocellulose membranes (Bio-Rad, Hercules, CA, USA). Subsequently, the membranes were blocked for $1 \mathrm{~h}$ at room temperature with $5 \%$ nonfat milk in TBST (25 mM Tris- $\mathrm{HCl}(\mathrm{pH} 7.5), 125 \mathrm{mM} \mathrm{NaCl}$, and $0.1 \%$ Tween-20) and incubated overnight at $4^{\circ} \mathrm{C}$ with specific primary antibodies against CD133 (Cell Applications, San Diego, CA, USA), $\beta$-catenin and $\beta$-actin (Cell Signaling, Danvers, MA, USA). Membranes were washed twice with TBST for $10 \mathrm{~min}$ and incubated with horseradish peroxidase-coupled secondary antibodies for $1 \mathrm{~h}$ at room temperature. The immune complexes were detected by Super 
a<smiles>O=c1cc(-c2ccc(O)cc2)oc2cc(O)c(C3OC(CO)[C@H](O)[C@H](O)[C@H]3O)c(O)c12</smiles>

Isovitexin

c

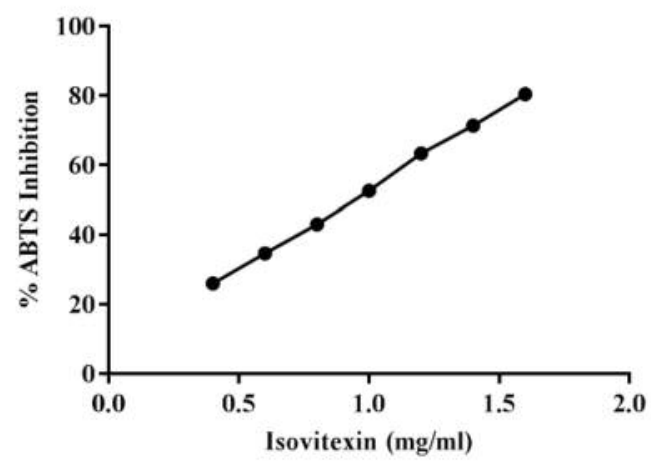

e

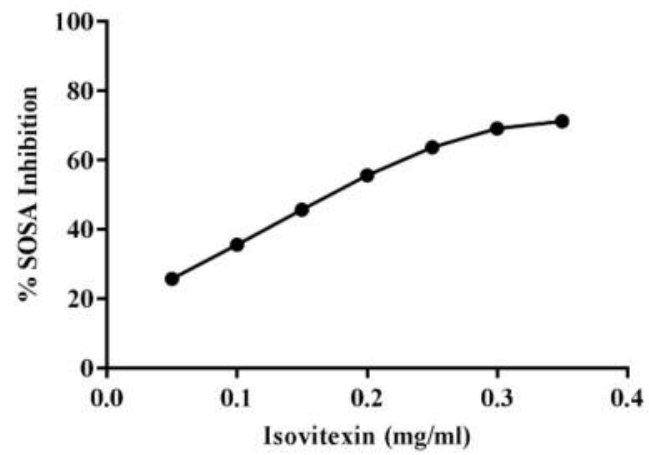

b

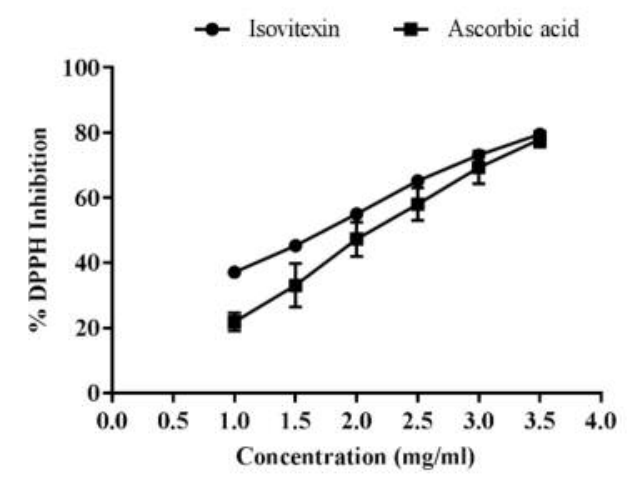

d

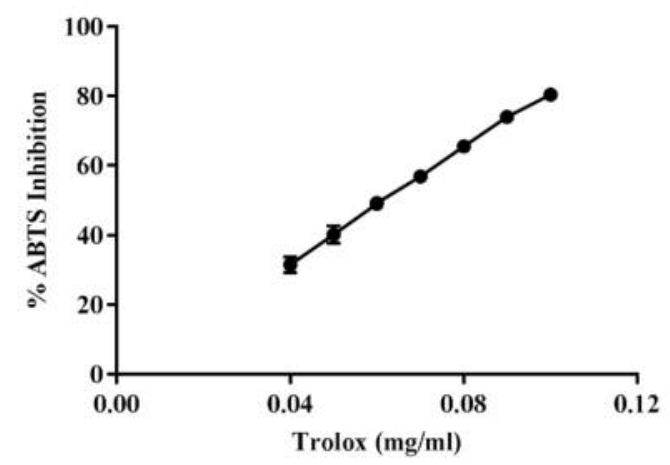

f

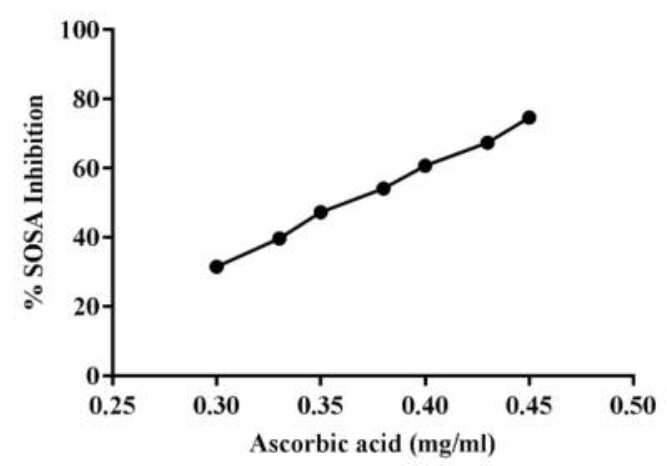

Figure 1. Chemical structure and antioxidant capacity of Isovitexin. (a) Isovitexin structure, Antioxidant activity of isovitexin against (b) DPPH radical $(c, d)$ ABTS radical $(e, f)$ Superoxide anion radical. All plots show the mean $\pm S D(n=3)$.

Signal West Pico Chemiluminescence substrate (Pierce Biotechnology, Rockford, IL, USA) and quantified using analyst/PC densitometry software (Bio-Rad, Hercules, CA, USA).

Statistical analysis. Data were normalized as mean \pm standard error of the mean (SEM). Experimental data were analyzed using GraphPad Prism software version 7 (GraphPad, San Diego, CA, USA). The statistical comparisons were carried out using one-way analysis of variance (ANOVA) followed by Tukey's post-hoc test
(SPSS, SPSS Inc., Chicago, IL, USA). A p-value less than 0.05 was considered statistically significant.

\section{Results}

Antioxidant activity of isovitexin. This study determined the antioxidant capacity of isovitexin against the DPPH radical, a free radical compound normally used for screening the 
a

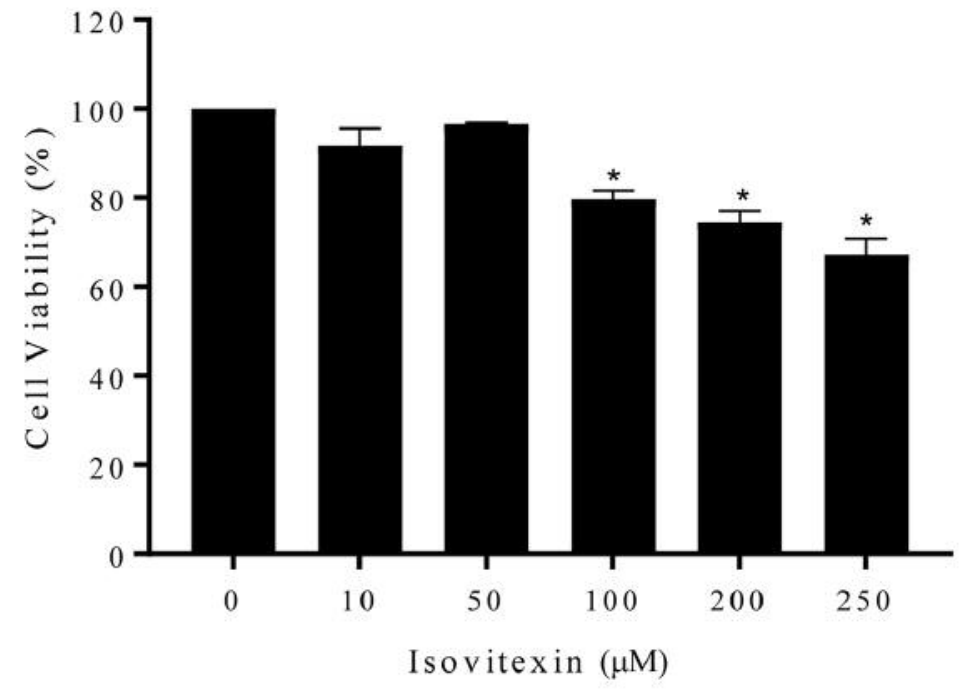

$\mathrm{b}$

HaCaT Cells

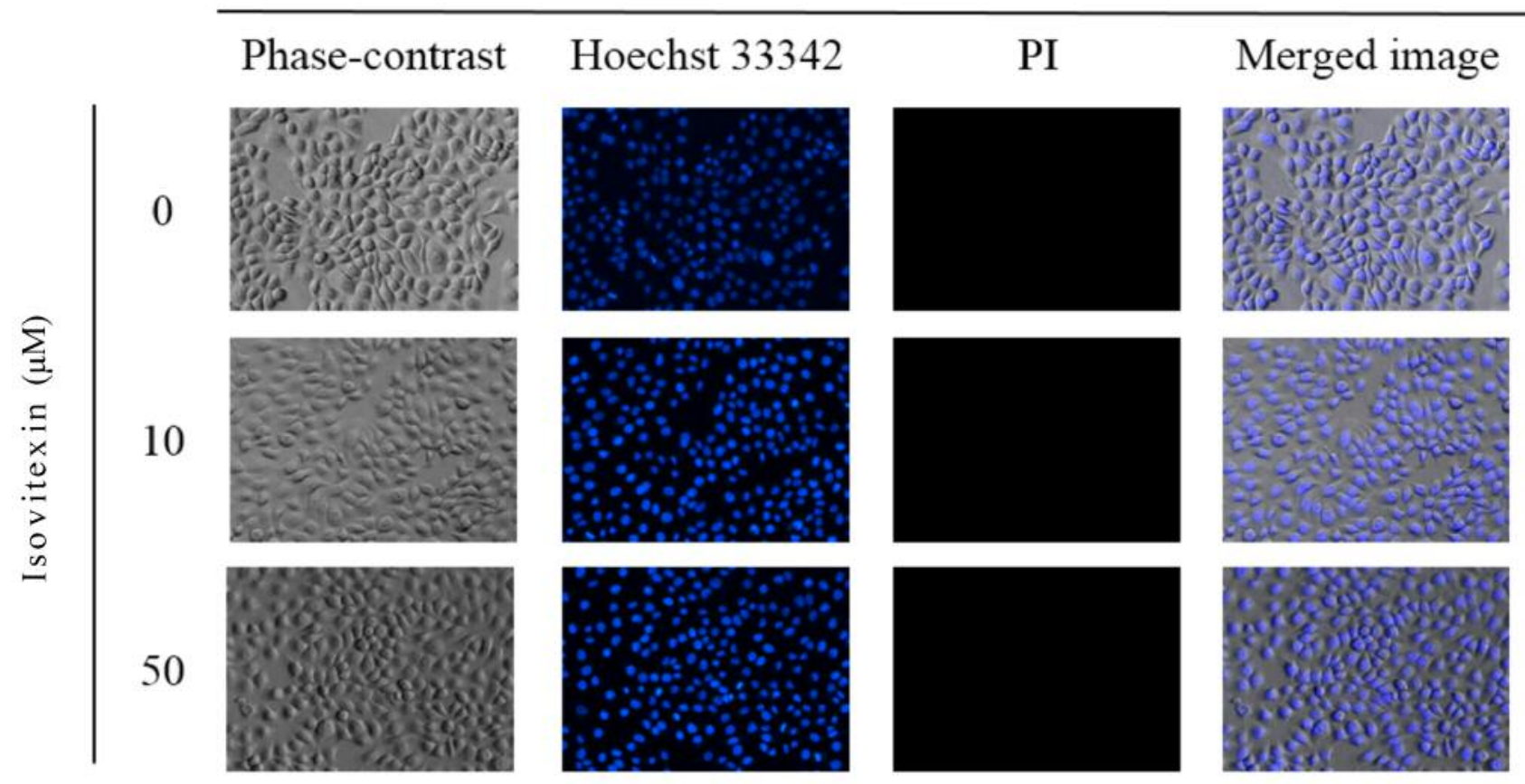

Figure 2. Effect of isovitexin on viability and cell death. (a) Cell viability of HaCaT cells treated with 0-250 $\mu$ M of isovitexin for 24 h (b) Apoptotic/necrotic cells were determined using Hoechst 33342 and Propidium iodide staining. All plots show the mean $\pm S D(n=3) . * p<0.05$ vs. untreated cells.

radical scavenging effect. The percentage of the scavenging activity of isovitexin ranged from 37.1 to $79.5 \%$ with $\mathrm{IC}_{50}$ at $1.72 \mathrm{mg} / \mathrm{ml}$ (Figure 1b). The percentage of the scavenging activity of the standard compound, ascorbic acid, ranged from 21.9 to $78.0 \%$ with an $\mathrm{IC}_{50}$ of 2.19 $\mathrm{mg} / \mathrm{ml}$. The $\mathrm{IC}_{50}$ of isovitexin was lower than that of ascorbic acid indicating that isovitexin has higher antioxidant capacity than ascorbic acid.
Furthermore, the calculation of the total antioxidant activity was investigated based on the decolorization of ABTS $^{\bullet+}$. The results are shown as $\%$ inhibition of ABTS $^{\bullet+}$ radical by isovitexin (Figure 1c) or trolox (Figure 1d), a standard compound, suppressed the absorbance of the $\mathrm{ABTS}^{\bullet+}$ radical in a dose-dependent manner. The $\mathrm{IC}_{50}$ of \%inhibition of $\mathrm{ABTS}^{\bullet+}$ by isovitexin and trolox were $0.94 \pm 0.01$ and $0.06 \pm 0.01 \mathrm{mg} / \mathrm{ml}$, respectively. 
a

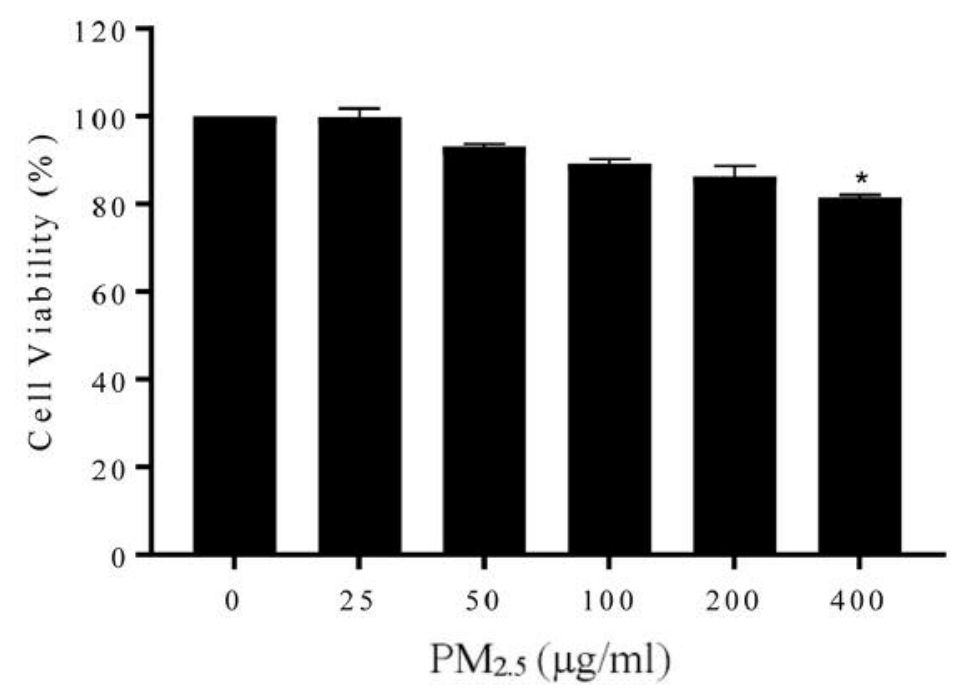

b

HaCaT Cells

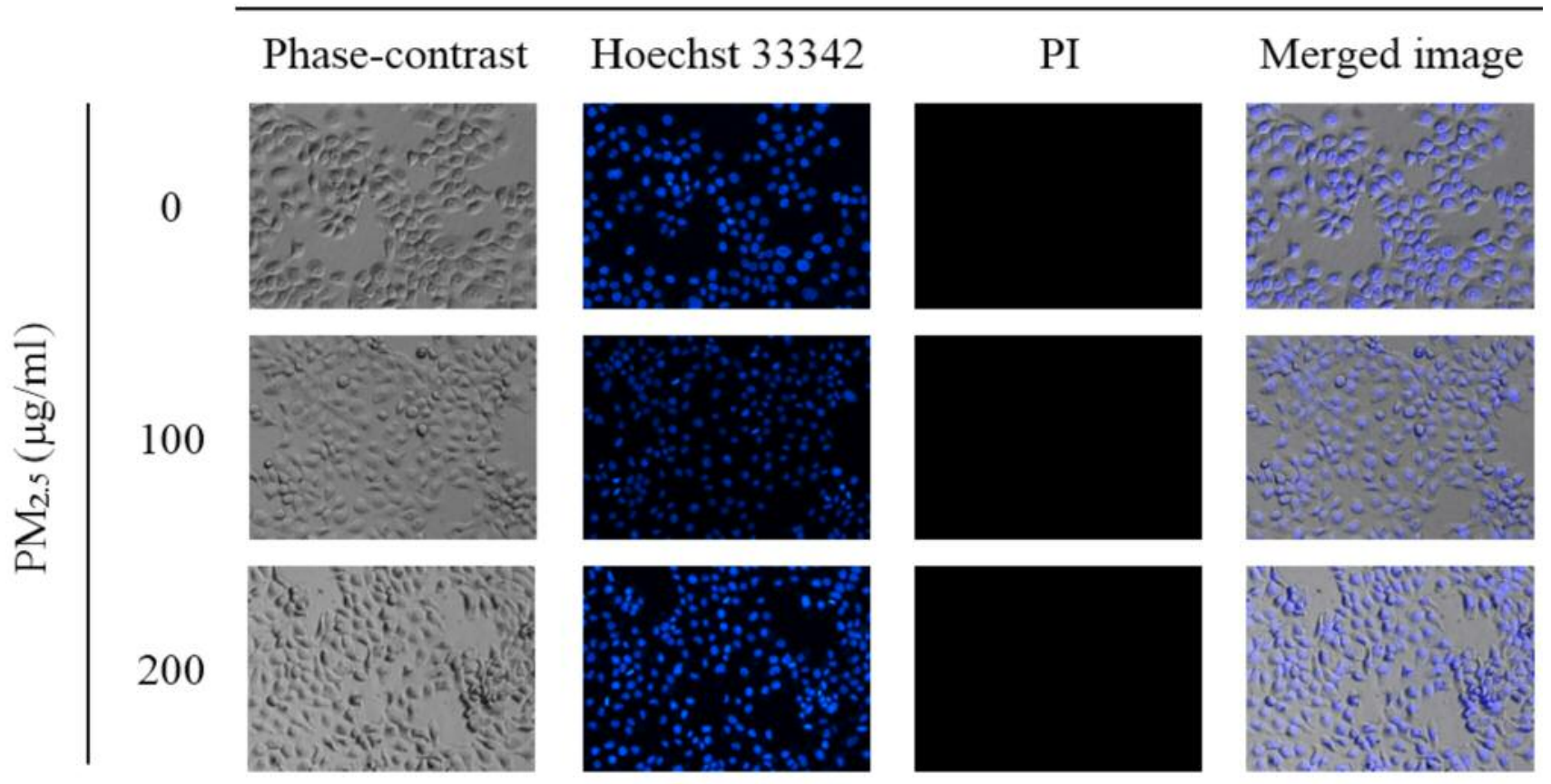

Figure 3. PM 2.5 induces apoptosis of keratinocytes. (a) Cell viability of HaCaT cells treated with 0-400 $\mu \mathrm{g} / \mathrm{ml}$ of PM 2.5 for $24 \mathrm{~h} .(\mathrm{b})$ Apoptotic/necrotic cells were determined using Hoechst 33342 and Propidium iodide staining. All plots show the mean $\pm S D(n=3)$. *p $<0.05$ vs. untreated cells.

The antioxidant capacity of isovitexin was tested against superoxide anion by determining SOSA. The $\mathrm{IC}_{50}$ of SOSA inhibition by isovitexin or ascorbic acid were 0.18 and $0.36 \mathrm{mg} / \mathrm{ml}$, respectively (Figure 1e and 1f). These results indicated that isovitexin has higher antioxidant capacity against superoxide anion than ascorbic acid.
Effect of isovitexin on the viability of human keratinocyte cells. Isovitexin was first assessed in human keratinocyte (HaCaT) cells. To determine the non-toxic doses of isovitexin to be used in the following experiments, $\mathrm{HaCaT}$ cells were treated with isovitexin at the concentrations of $0-250 \mu \mathrm{M}$ and cell viability was determined after $24 \mathrm{~h}$ by MTT viability assay. Treatment of the cells with $0-50 \mu \mathrm{M}$ 
a
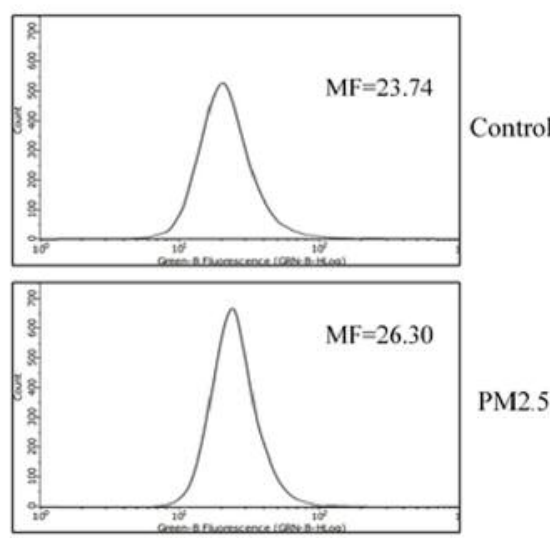

PM2.5 $100 \mu \mathrm{gml}$
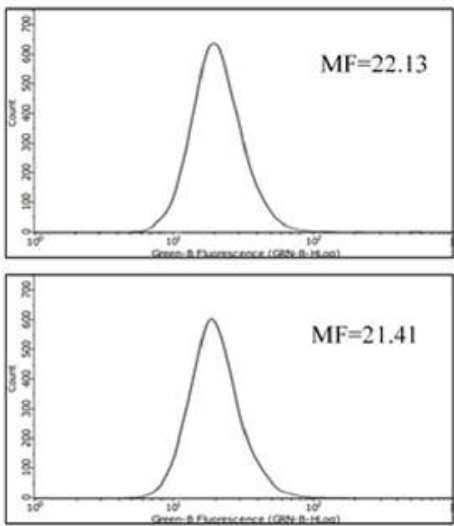

C

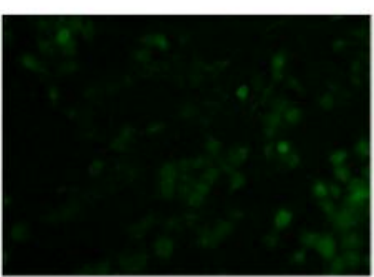

Control

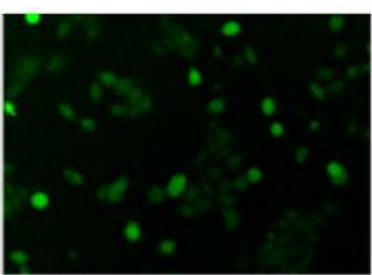

Isovitexin $(0 \mu \mathrm{M})$

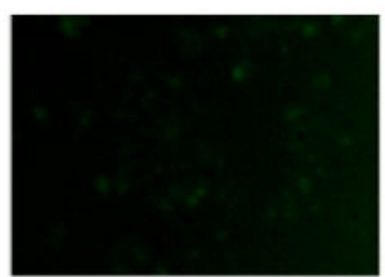

Isovitexin $(10 \mu \mathrm{M})$

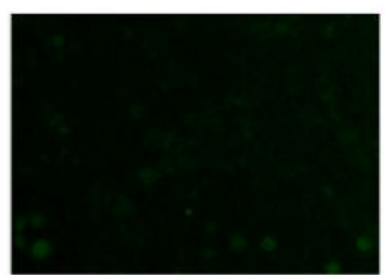

Isovitexin $(50 \mu \mathrm{M})$ b

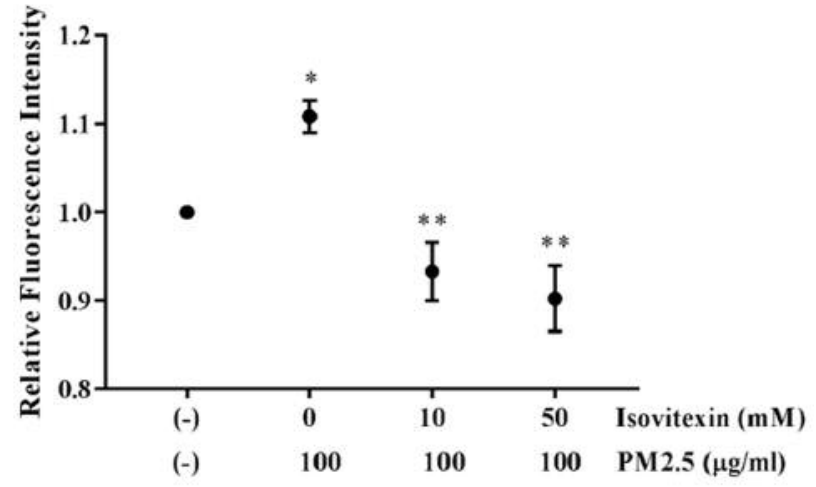

\section{PM2.5 $(100 \mu \mathrm{g} / \mathrm{ml})$}

Figure 4. Protective effect of isovitexin on PM ${ }_{2}$-induced ROS. (a) Cells loaded with DCFH-DA were pretreated with isovitexin for 30 min and then incubated with $100 \mu \mathrm{g} / \mathrm{ml} P M_{2.5}$ for $30 \mathrm{~min}$. The levels of ROS were determined by flow cytometry. (b) The fluorescence intensity form flow cytometry analysis. (c) The intracellular fluorescence of cells pretreated with isovitexin and treated with PM 2.5 was captured by fluorescence microscope. Data are shown as the mean $\pm S D(n=3)$. ${ }^{*} p<0.05$ compared to control groups and ${ }^{* *} p<0.05$ compared to PM 2.5 -treated groups.

isovitexin caused no significant change in cell viability compared with the non-treated control (Figure 2a). The evaluation of cell death via Hoechst33342 staining also showed that $0-50 \mu \mathrm{M}$ isovitexin did not cause any change in nuclear morphology of $\mathrm{HaCaT}$ cells (Figure 2b), revealing that the concentrations of the compound up to $50 \mu \mathrm{M}$ do not induce apoptosis. This information clarified that the following effects of 0-50 $\mu \mathrm{M}$ isovitexin on $\mathrm{HaCaT}$ cells were not a consequence of cytotoxicity or cell stress.

Cytotoxic effect of $\mathrm{PM}_{2.5}$ on $\mathrm{HaCaT}$ Cells. It is interesting to elucidate whether $\mathrm{PM}_{2.5}$ has a direct cytotoxic effect on 
a

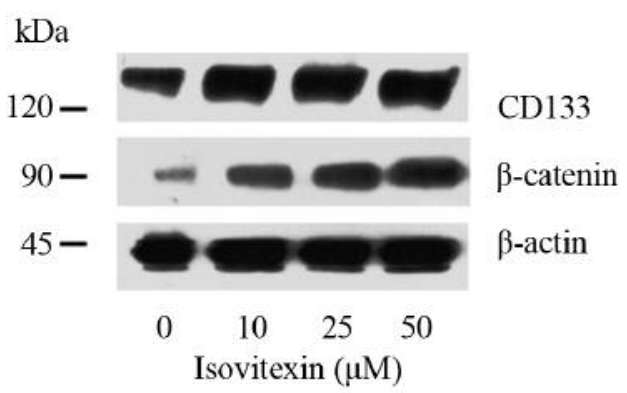

b $\mathbf{a}$ CD133 $\mathbf{\square} \beta$-catenin

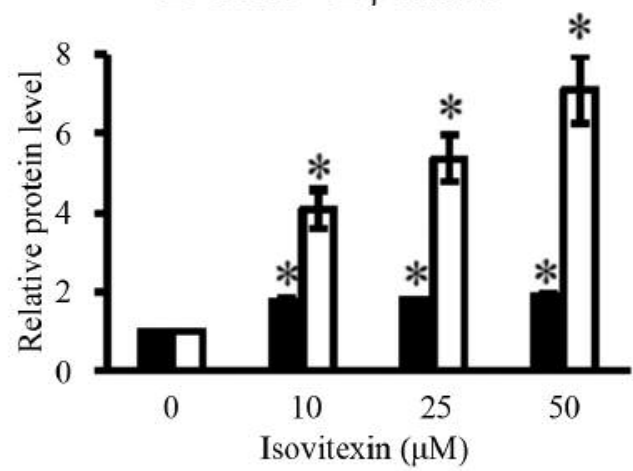

Figure 5. Effect of isovitexin on stem cell markers. (a) The expression levels of CD133 and $\beta$-catenin were determined by western blotting. (b) Relative protein levels were quantified by densitometry. Data are presented as mean $\pm S D(n=3)$. ${ }^{*}<0.05$ versus non-treated control.

keratinocytes. We next evaluated the effect of $\mathrm{PM}_{2.5}$ exposures on cell survival of HaCaT cells. The cells were cultured in the absence or presence of $\mathrm{PM}_{2.5}$ at various concentrations and the viability of the cells was examined by the MTT assay. Figure 3a shows that after the treatment of the cells with $0,25,50,100$ and $200 \mu \mathrm{g} / \mathrm{ml} \mathrm{PM}_{2.5}$, no statistically significant effect on cell viability was detected compared with the non-treated control cells. Figure $3 b$ indicates normal morphology of the nucleus of $\mathrm{PM}_{2.5^{-}}$ treated cells that were stained with Hoechst 33342 and examined under a fluorescent microscope, indicating no apoptosis response at these concentrations. Also, the cell membrane integrity evaluated by propidium iodide staining showed no significant increase in necrotic cells. These results indicated that $\mathrm{PM}_{2.5}$ at concentrations up to 200 $\mu \mathrm{g} / \mathrm{ml}$ did not cause direct cell death in human keratinocyte cells.

Protective effect of isovitexin on $P M_{2.5}$-induced ROS. Next, we examined whether treatment with non-toxic concentrations of $\mathrm{PM}_{2.5}(100 \mu \mathrm{g} / \mathrm{ml})$ induces significant increase in the level of intracellular ROS. The histograms obtained from flow cytometry analysis of DCFH-DA demonstrated a dramatic increase in ROS production in $\mathrm{PM}_{2.5}$-treated cells (Figure 4a). The mean fluorescent intensity demonstrated that there was increase in ROS levels after incubation with $\mathrm{PM}_{2.5}$ for 30 min compared with nontreated control cells (Figure 4b). Interestingly, pretreatment with 10-50 $\mu \mathrm{M}$ isovitexin completely abolished $\mathrm{PM}_{2.5^{-}}$ induced elevation of ROS levels. Figure 4c indicates the accumulation of cellular ROS detected by DCFH-DA fluorescent probe under fluorescent microscope. The green fluorescence of DCFH-DA was barely noticed in isovitexinpretreated cells compared to highly intense fluorescence signal in $\mathrm{PM}_{2.5}$-treated cells.
Isovitexin increases expression of stem cell markers. It is known that tissue functions rely on the activities of stem cells. To test whether isovitexin could enhance stemness of human keratinocytes, the expression of molecular markers of stem cells were determined after exposing the cells to nontoxic concentrations of isovitexin. CD133 and $\beta$-catenin have been recognized as indicators of stemness of cells. Cells were treated with isovitexin for $48 \mathrm{~h}$ and the expression levels of CD133 and $\beta$-catenin were determined by western blot analysis. Treatment with 10-50 $\mu \mathrm{M}$ isovitexin significantly increased expression of CD133 and $\beta$-catenin in a concentration-dependent manner (Figure 5).

\section{Discussion}

Environmental pollution is an important factor leading to skin damage (18). Recently, a critical concern has been developed about air pollutants and especially particular matter, due to their wide distribution in the atmosphere. Because of its small size, $\mathrm{PM}_{2.5}$ can escape human body protection mechanisms and accumulate in various human tissues (19). The cellular damage caused by submicron particles including $\mathrm{PM}_{2.5}$ has been reported by several studies and additional evidence will gradually accumulate $(20,21)$.

As the epidermis layer of the skin provides a key protection for all skin layers, it has been shown that disturbance or dysregulation of epidermal barrier function contributes to several skin disorders including hypersensitivity and ageing (22). An important mechanism that underlies the decrease in epidermal heath and function is keratinocyte damage caused by high levels of intracellular ROS (23). Intracellular ROS has been shown to be induced by exposure to $\mathrm{PM}_{2.5}$ (24). In this study, we also found that $\mathrm{PM}_{2.5}$ is able to generate ROS in human keratinocytes (Figure 4). Although high concentrations of $\mathrm{PM}_{2.5}$ (100-200 
$\mu \mathrm{g} / \mathrm{ml})$ did not have a significant effect on cell viability (Figure $3 \mathrm{a}$ and $\mathrm{b}$ ), the dramatic increase in cellular ROS confirmed the potential of $\mathrm{PM}_{2.5}$ to generate damage (Figure 4). ROS have been known as dangerous molecules leading to skin aging. ROS cause abnormalities and oxidative stress in keratinocytes. Macromolecules and organelles such as mitochondria, endoplasmic reticulum and lysosome are damaged by ROS (25). The results obtained from this study suggested that $\mathrm{PM}_{2.5}$ is a strong ROS inducer and a critical factor of skin damage.

Antioxidants have been proposed as effective skin protectors (26). Additionally, antioxidant compounds derived from natural sources have gained interest for cosmetic application due to their safe profile in humans (27). Among many natural compounds, isovitexin extracted from Phaseolus radiatus $\mathrm{L}$. and germinated fenugreek seeds possesses high antioxidant capacity $(14,28)$. Furthermore, isovitexin treatment has been shown to reduce LPS-induced proinflammatory cytokine secretion, expression of iNOS and COX-2 and suppress ROS production in RAW 264.7 mouse macrophage cell line (29). The potential benefits of isovitexin as skin protectant was first revealed in this study. Pretreatment with isovitexin effectively restored cellular ROS levels in human keratinocyte cells exposed with $\mathrm{PM}_{2.5}$ (Figure $4 \mathrm{~b}$ ). Isovitexin also exhibited a promising antioxidant activity as evidenced by the low $\mathrm{IC}_{50}$ in scavenging various types of free radicals (Figure 1). Superoxide anions have been recognized as harmful free radicals causing skin damage especially in keratinocytes (30). Interestingly, isovitexin demonstrated higher ability in reducing superoxide anions than vitamin $\mathrm{C}$, a well-known antioxidant (Figure 1e and 1f). This result confirms the potential benefits of isovitexin in the prevention of skin damage. The induction of stemness signals including $\beta$-catenin and CD133 were detected in isovitexin treatedkeratinocytes (Figure 5a and 5b). Stemness of skin cells was previously reported to associate with the induction of $\beta$ catenin pathway (31).

In summary, isovitexin exerts stem cell properties and protective effects against $\mathrm{PM}_{2.5}$-induced $\mathrm{ROS}$ in human keratinocyte cells. This information strengthens the potential development of isovitexin as a natural antioxidant compound for skin product application.

\section{Conflicts of Interest}

The Authors declare that they have no competing interests regarding this study.

\section{Authors' Contributions}

$\mathrm{VC}, \mathrm{KJ}$ and PC designed, performed and analyzed the experiments. TP collected the $\mathrm{PM}_{2.5}$. VC performed the ROS and oxidative stress experiments. All Authors reviewed the results and approved the final version of the manuscript.

\section{Acknowledgements}

This study was supported by The Thailand Research Fund (RSA6180036) and The Research Institute of Rangsit University (Grant no. 31/2561), Rangsit University.

\section{References}

1 Kelly FJ and Fussell JC: Air pollution and public health: Emerging hazards and improved understanding of risk. Environ Geochem Health 37(4): 631-649, 2015. PMID: 26040976. DOI: 10.1007/s10653-015-9720-1

2 Meng J, Liu J, Xu Y, Guan D, Liu Z, Huang Y and Tao S: Globalization and pollution: Tele-connecting local primary pm2.5 emissions to global consumption. Proc Math Phys Eng Sci 472(2195): 20160380, 2016. PMID: 27956874. DOI: 10.1098/rspa.2016.0380

3 Singh N, Murari V, Kumar M, Barman SC and Banerjee T: Fine particulates over south asia: Review and meta-analysis of pm2.5 source apportionment through receptor model. Environ Pollut 223: 121-136, 2017. PMID: 28063711. DOI: 10.1016/j.envpol. 2016.12.071

4 Deng X, Zhang F, Rui W, Long F, Wang L, Feng Z, Chen D and Ding W: Pm2.5-induced oxidative stress triggers autophagy in human lung epithelial a549 cells. Toxicol In Vitro 27(6): 17621770, 2013. PMID: 23685237. DOI: 10.1016/j.tiv.2013.05.004

5 Ying Z, Xu X, Bai Y, Zhong J, Chen M, Liang Y, Zhao J, Liu D, Morishita M, Sun Q, Spino C, Brook RD, Harkema JR and Rajagopalan S: Long-term exposure to concentrated ambient pm2.5 increases mouse blood pressure through abnormal activation of the sympathetic nervous system: A role for hypothalamic inflammation. Environ Health Perspect 122(1): 7986, 2014. PMID: 24240275. DOI: 10.1289/ehp.1307151

6 Monn C and Becker S: Cytotoxicity and induction of proinflammatory cytokines from human monocytes exposed to fine $(\mathrm{pm} 2.5)$ and coarse particles $(\mathrm{pm} 10-2.5)$ in outdoor and indoor air. Toxicol Appl Pharmacol 155(3): 245-252, 1999. PMID: 10079210. DOI: 10.1006/taap.1998.8591

7 Kim YM, Kim J, Jung K, Eo S and Ahn K: The effects of particulate matter on atopic dermatitis symptoms are influenced by weather type: Application of spatial synoptic classification (ssc). Int J Hyg Environ Health 221(5): 823-829, 2018. PMID: 29853291. DOI: $10.1016 /$ j.ijheh.2018.05.006

8 Vierkotter A, Schikowski T, Ranft U, Sugiri D, Matsui M, Kramer U and Krutmann J: Airborne particle exposure and extrinsic skin aging. J Invest Dermatol 130(12): 2719-2726, 2010. PMID: 20664556. DOI: 10.1038/jid.2010.204

9 Jin SP, Li Z, Choi EK, Lee S, Kim YK, Seo EY, Chung JH and Cho $S$ : Urban particulate matter in air pollution penetrates into the barrier-disrupted skin and produces ros-dependent cutaneous inflammatory response in vivo. J Dermatol Sci 91(2): 175-183, 2018. PMID: 29731195. DOI: 10.1016/j.jdermsci.2018.04.015

10 Rinnerthaler M, Bischof J, Streubel MK, Trost A and Richter K: Oxidative stress in aging human skin. Biomolecules 5(2): 545589, 2015. PMID: 25906193. DOI: 10.3390/biom5020545

11 Choo CY, Sulong NY, Man F and Wong TW: Vitexin and isovitexin from the leaves of Ficus deltoidea with in vivo alphaglucosidase inhibition. J Ethnopharmacol 142(3): 776-781, 2012. PMID: 22683902. DOI: 10.1016/j.jep.2012.05.062 
12 Wang J, Tang F, Yue Y, Guo X and Yao X: Development and validation of an hptlc method for simultaneous quantitation of isoorientin, isovitexin, orientin, and vitexin in bamboo-leaf flavonoids. J AOAC Int 93(5): 1376-1383, 2010. PMID: 21140646.

13 Zhang J, Yuan K, Zhou WL, Zhou J and Yang P: Studies on the active components and antioxidant activities of the extracts of Mimosa pudica linn. from southern China. Pharmacogn Mag 7(25): 35-39, 2011. PMID: 21472077. DOI: 10.4103/09731296.75899

14 Khole S, Chatterjee S, Variyar P, Sharma A, Devasagayam TPA and Ghaskadbi S: Bioactive constituents of germinated fenugreek seeds with strong antioxidant potential. J Funct Foods 6: 270-279, 2014. DOI: 10.1016/j.jff.2013.10.016

15 Shibano M, Kakutani K, Taniguchi M, Yasuda M and Baba K: Antioxidant constituents in the dayflower (Commelina communis 1.) and their alpha-glucosidase-inhibitory activity. J Nat Med 62(3): 349-353, 2008. PMID: 18409066. DOI: 10.1007/s11418 008-0244-1

16 Hou D, Yousaf L, Xue Y, Hu J, Wu J, Hu X, Feng N and Shen Q: Mung bean (Vigna radiata 1.): Bioactive polyphenols, polysaccharides, peptides, and health benefits. Nutrients 11(6), 2019. PMID: 31159173. DOI: 10.3390/nu11061238

17 Hu R, Xie XY, Xu SK, Wang YN, Jiang M, Wen LR, Lai W and Guan L: Pm2.5 exposure elicits oxidative stress responses and mitochondrial apoptosis pathway activation in hacat keratinocytes. Chin Med J (Engl) 130(18): 2205-2214, 2017. PMID: DOI: 10.4103/0366-6999.212942

18 Bickers DR and Athar M: Oxidative stress in the pathogenesis of skin disease. J Invest Dermatol 126(12): 2565-2575, 2006. PMID: 17108903 . DOI: $10.1038 /$ sj.jid.5700340

19 Kim KE, Cho D and Park HJ: Air pollution and skin diseases: Adverse effects of airborne particulate matter on various skin diseases. Life Sci 152: 126-134, 2016. PMID: 27018067. DOI: 10.1016/j.lfs.2016.03.039

20 Gualtieri M, Ovrevik J, Mollerup S, Asare N, Longhin E, Dahlman HJ, Camatini $\mathrm{M}$ and Holme JA: Airborne urban particles (milan winter-pm2.5) cause mitotic arrest and cell death: Effects on DNA, mitochondria, AhR binding and spindle organization. Mutat Res 713(1-2): 18-31, 2011. PMID: 21645525. DOI: $10.1016 / \mathrm{j} . \mathrm{mrfmmm} .2011 .05 .011$

21 Mazzarella G, Lucariello A, Bianco A, Calabrese C, Thanassoulas T, Savarese L, Fiumarella A, Esposito V and A DEL: Exposure to submicron particles (pm1.0) from diesel exhaust and pollen allergens of human lung epithelial cells induces morphological changes of mitochondria tonifilaments and rough endoplasmic reticulum. In Vivo 28(4): 557-561, 2014. PMID: 24982222.

22 Tobin DJ: Introduction to skin aging. J Tissue Viability 26(1): 37-46, 2017. PMID: 27020864. DOI: 10.1016/j.jtv.2016.03.002
23 Rinnerthaler M, Bischof J, Streubel MK, Trost A and Richter K: Oxidative stress in aging human skin. Biomolecules 5(2): 545589, 2015. PMID: 25906193. DOI: 10.3390/biom5020545

24 Rui W, Guan LF, Zhang F, Zhang W and Ding WJ: Pm2.5induced oxidative stress increases adhesion molecules expression in human endothelial cells through the erk/akt/nf-kappa bdependent pathway. J Appl Toxicol 36(1): 48-59, 2016. PMID: 25876056. DOI: 10.1002/jat.3143

25 Piao MJ, Ahn MJ, Kang KA, Ryu YS, Hyun YJ, Shilnikova K, Zhen AX, Jeong JW, Choi YH, Kang HK, Koh YS and Hyun JW: Particulate matter 2.5 damages skin cells by inducing oxidative stress, subcellular organelle dysfunction, and apoptosis. Arch Toxicol 92(6): 2077-2091, 2018. PMID: 29582092. DOI: 10.1007/s00204-018-2197-9

26 Katiyar SK, Matsui MS, Elmets CA and Mukhtar $\mathrm{H}$ : Polyphenolic antioxidant (-)-epigallocatechin-3-gallate from green tea reduces uvb-induced inflammatory responses and infiltration of leukocytes in human skin. Photochem Photobiol 69(2): 148-153, 1999. PMID: 10048310. DOI: 10.1111/j.17511097.1999.tb03267.x

27 Stojiljkovic D, Tadic V, Stankovic M, Roganovic S and Arsic I: Standardized extract of wild apple fruit in alkyl-polyglucosidebased cosmetic cream - estimation of stability, safety, antioxidant activity and efficiency. Int J Cosmet Sci 40(3): 285-294, 2018. PMID: 29723433. DOI: 10.1111/ics.12462

$28 \mathrm{Li} \mathrm{H}$, Cao D, Yi J, Cao J and Jiang W: Identification of the flavonoids in mungbean (Phaseolus radiatus L.) soup and their antioxidant activities. Food Chem 135(4): 2942-2946, 2012. PMID: 22980894. DOI: 10.1016/j.foodchem.2012.07.048

29 Lv H, Yu Z, Zheng Y, Wang L, Qin X, Cheng G and Ci X: Isovitexin exerts anti-inflammatory and anti-oxidant activities on lipopolysaccharide-induced acute lung injury by inhibiting MAPK and NF-kB and activating $\mathrm{HO}-1 / \mathrm{Nrf} 2$ pathways. Int $\mathbf{J}$ Biol Sci 12(1): 72-86, 2016. PMID: 26722219. DOI: 10.7150/ ijbs. 13188

30 Lephart ED: Skin aging and oxidative stress: Equol's anti-aging effects via biochemical and molecular mechanisms. Ageing Res Rev 31: 36-54, 2016. PMID: 27521253. DOI: 10.1016/ j.arr.2016.08.001

31 Rattanachitthawat N, Pinkhien T, Opanasopit P, Ngawhirunpat T and Chanvorachote P: Finasteride enhances stem cell signals of human dermal papilla cells. In Vivo 33(4): 1209-1220, 2019. PMID: 31280211. DOI: 10.21873/invivo.11592

Received August 8, 2019

Revised September 15, 2019 Accepted September 16, 2019 